\title{
ALI ABDUL RAZIQ KAJIAN TEOLOGIS ATAS PEMIKIRANNYA
}

\author{
Oleh: \\ Burhanuddin Yusuf \\ Dosen Aqidah dan Filsafat Islam \\ Fakultas Ushuluddin, Filsafat dan Politik \\ UIN Alauddin Makassar
}

\begin{abstract}
Abstrak
Ali Abdul Razik adalah pemikir muslim yang dinilai kontroversial karena pemikiran politiknya. Hal ini terjadi karena kajiannya berbeda arus dari pemikiran tokoh-tokoh muslim sezamannya, terutama dalam hal pemerintahan Islam. Pandangan Ali Abdul Raziq sungguh pun lebih berat menggunakan pendekatan sejarah dan logika social, suatu pendekatan yang memang jarang digunakan oleh ulama pada umumnya, namun alasan-alasan teologis dibalik itu cukup kental kelihatan untuk memahami hal terebut, pengkaji perlu lebih kritis.

Kerangka berfikir Ali Abdul Raziq oleh ulama sunni umumnya dianggap cendrung melahirkan Negara sekuler, yaitu Negara yang tidak bertanggungjawab pada persoalan-persoalan agama. Inilah yang menjadi kunci penentangan mereka kepada pemikiran ali Abdul Raziq.

Ali Abdul Raziq menegaskan bahwa dari kaca mata Al-Qur'an maupun Sunnah, tidak ditemukan matan yang bersifat teologis tentang adanya bentuk pemerintahan tertentu yang wajib diikuti atau diterapkan oleh umat Islam. Implikasinya adalah, Rasulullah saw cukup bijak memberi ruang kepada umatnya untuk memilih bentuk pemerintahan yang sesuai untuknya. Oleh karena itu, maka bentuk pemerintahan umat Islam dari masa kemasa tidak bersifat passif, tidak kaku, selalu up to date.
\end{abstract}

\section{Keywords:}

Ali Abdul Razik, Khilafah, Pemerintahan Islam, Politik

\section{PENDAHULUAN}

Ali Abdul Razik adalah pemikir muslim yang dinilai kontroversial karena pemikiran politiknya. Hal ini terjadi karena kajiannya berbeda arus dari pemikiran tokoh-tokoh muslim sezamannya, terutama dalam hal pemerintahan Islam.

Arus pemikiran tokoh muslim zamannya menunjukkkan bahwa kepemimpinan umat Islam secara umum adalah "khalifah." Institusi khalifah senidir bukan hanya atas tuntutan kepemimpinan dunia Islam, tapi dimaknai pula sebagai tuntutan Syariah. Artinya, Syariah dalam hal ini Alquran dan Hadist Rasulullah saw. mewajibkan adanya kepemimpinan khalifah bagi umat Islam. Kepemimpinan seperti ini tetap terpelihara, mulai priode Abu Bakar al-Shiddiq sampai dengan berakhirnya kekuasaan sultan-sultan yang berkuasa di kerjaan Turki Usmani.

Perang Dunia I (1914-1918) membawa dampak yang sangat besar bagi Turki. Pengakuan Sekutu kepada Turki pimpinan Mustafa Kemal Attaturk mengharuskan Negara itu berbentuk Republik. Konsekwensi lanjutannya adalah 
institusi pemerintahan harus menyesuaikan dan karenanya memunculkan Negara baru bagi Turki yang sangat lain dari sebelumnya.

Sesungguhnya, perubahan drastic tersebut tidak merupakan keinginan secara utuh dari pemenang perang dunia I (Sekutu), namun juga karena keinginan dari Mustafa Kemal dan rezimnya. Persitiwa-peristiwa sejak setelah proklamasi dicanangkan di tahun 1923, memperlihatkan terjadinya perubahan berlangsung secara terencana dan sistematis, pelan namun pasti.

Rentetan perubahan mendasar yang terjadi di Turki terlihat terutama ketika sidang Majelis Agung Turki yang dipimpin Mustafa Kemal memutuskan bahwa kekuasaan tertinggi berada di tangan rakyat, bukan di tangan khalifah atau Sultan. Selanjutnya, pada sidang majelis tahun 1923, jabatan sultan dihapus dan diganti dengan Negara Republic. Dengan begitu, system pemerintahan Turki berobah secara totalitas, dari bentuk kesultanan di bawah kepemimpinan Sultan dan khalifah berganti menjadi republik di bawah kepemimpinan presiden, dalam hal ini, Mustafa Kemal sebagai Presiden pertamanya.

Keputusan Majelis Agung yang paling kontroversial dan sempat menghebohkan dunia Islam adalah ketika institusi atau jabatan Khalifah dihapuskan. Seperti diketahui bahwa sejak khalifah terakhir dari daulah Abbasiyah memberi mandat khalifah kepada sultan-sultan yang berkuasa di Turki, maka jabatan tersebut diemban oleh penguasa Turki sampai Mustafa Kemal dengan majelis Agungnya menghapuskannya pada tanggal 3 Maret 1924. Khalifah Abdul Majid dan keluarganya diperintahkan meninggalkan Turki. ${ }^{1}$

Penghapusan jabatan khalifah yang dilakukan oleh Mustafa Kemal tersebut sudah pasti menghebohkan dunia Islam. Secara umum, pemimpin-pemimpin Islam di dunia mengecam, menyayangkan dan bahkan ada yang mencap Mustafa Kemal dan rezimnya sudah di luar Islam. Sungguhpun demikian, ada juga tokoh dan atau ulama yang membenarkannya, palig tidak, abstain untuk memberi penilaian negative atasnya.

Di antara tokoh yang tidak memberi respon megatif atas penghapusan jabatan "khalifah" oleh Mustafa Kemal dan fezimnya itu adalah Ali Abdul Raziq, seorang tokoh rasionalis kelahiran Mesir di tahun 1888. Pandangannya yang tidak lazim pada saat itu tertuang dalam bukunya yang berjudul Al-Islam wa Al-Hukm. Tak dapat disangsikan bahwa di kalangan muslim terjadi perdebatan sengit antara pandangan yang menyalahkan dengan yang membenarkan penghapusan institusi khalifah yang dilakukan oleh Mustafa Kemal tersebut.

Secara umum, ulama Islam (sunni) pada saat itu berpendapat bahwa system Khilafah adalah bagian dari ajaran dasar dalam Islam. Ini antara lain dipahami dari firman Allah swt pada dalam QS al-Nur /24 :54 sbb:

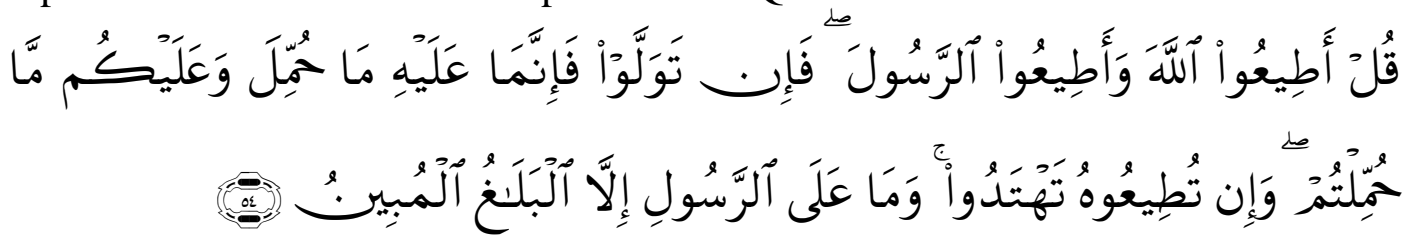

Terjemahnya:

Katakanlah: "Taat kepada Allah dan taatlah kepada rasul; dan jika kamu berpaling Maka Sesungguhnya kewajiban Rasul itu adalah apa yang 
dibebankan kepadanya, dan kewajiban kamu sekalian adalah semata-mata apa yang dibebankan kepadamu. dan jika kamu taat kepadanya, niscaya kamu mendapat petunjuk. dan tidak lain kewajiban Rasul itu melainkan menyampaikan (amanat Allah) dengan terang".

Ali Abd Al-Raziq berpendirian bahwa system pemerintahan, tidak diatur dalam Al-Qur'an dan Hadis. Dari dua sumber dasar Islam tersebut, tidak ditemukan informasi yang sarih tentang system pemerintahan yang harus dijalankan oleh umat Islam; demgam kata lain, ajaran Islam tidak menentukan corak Negara tertentu yang wajib diikuti. ${ }^{2}$ sistem pemerintahan dapat diubah yang disesuaikan dengan zaman dan kondisi masing-masing wilayah atau negara.

Pandangan Ali Abdul Razik tersebut sudah tentu mendapat tantangan dari ulama-ulama pada umumnya, terutama menjelang kongres Khilafah 1 yang diselenggarakan di Kairo pada tanggal 13 Mei 1926.3. Diantara ulama yang menetangnya adalah Muhammad Rasyid Ridha yang mempertahankan system Khilafah dan menuduh Ali Abd al-Raziq melemahkan Islam. Tantangan keras datang dari ulama Al-Azhar. Dalam rapat Majelis Ulama Besar diputuskan bahwa pendapat Ali Abd al-Raziq itu bertentangan dengan Islam. Oleh sebab itu ia tidak diakui sebagai ulama dan namanya dicoret daru daftar ulama Azhar dan dipecat dari jabatannya sebagai hakim agama. ${ }^{4}$

Tulisan ini berupaya mengungkap muatan teologis yang melandasi pandangan Ali Abdul Razik melalui pemikirannya tentang "khilafah"

\section{SEKILAS TENTANG ALI ABD AL-RAZIQ}

Ali Abd al-Raziq lahir Pada tahun 1888 di pedalaman Mesir propinsi Menia. Ayahnya bernama Hasan Abd al-Razik seorang Pasya yang cukup berpengaruh karena memiliki tanah yang luas. Hasan lebih banyak berkecimpung dalam dunia politik dan pernah menjadi wakil ketua partai Hizb al-Ummah pada tahun 1907. Saudara Ali Abd al-Raziq bernama Pasya Abd al-Razik pernah menjabat kepala Sultan Husein yang merupakan agen Inggris pada masa perang dunia I. Pasya Abd al-Raziq terbunuh pada tahun 1922. Saudaranya yang kedua bernama Mahmud Pasya Abd al-Raziq salah seorang pimpinan pusat partai Hizb al-Ummah. Partai Hizb al-Ummah ternyata partai berhubungan dekat dengan Inggris. ${ }^{5}$

Selanjutnya, Saudara Ali yang tertua bernama Mustafa Abd al-Raziq pernah menjabat sebagai menteri waqaf dan pada akhirnya ia menjabat sebagai Syekh al-Azhar. Seperti halnya Mustafa. Ali Abdul Raziq juga pernah diangkat menjadi menteri waqaf, anggota lembaga Bahasa Arab, serta beberapa jabatan penting lainnya. ${ }^{6}$ Dari sini dapat disimpulkan bahwa keluarga besar Hasan banyak berkecimpung di dunia politik dan Pendidikan.

Ali Abd al-Raziq mengikuti kuliah di al-Azhar pada akhir Muhammad Abduh masih aktif sebagai dosen pada lembaga tersebut sehingga kesempatannya menimba ilmu langsung dari Muhammad Abduh tidak sama lamanya dengan Mustafa dan ayahnya Hasan. Ali al-Razik belajar hukum dari Abu Khatwah sahabat Abduh, sedang Abu Khatwah adalah murid Jamaluddin al-Afghani. Ali tidak puas kuliah di al-Azhar sehingga merangkap kuliah pada al-Jami'ah alMisriyah sejak tahun 1910. Dosen asing yang diikuti kuliahnya adalah 
Prof.Mallino dengan mata kuliah sejarah kesusastraan Arab dengan Prof.Sentillana dalam mata kuliah filsafat. ${ }^{7}$

Setelah Ali al-Razik memperoleh ijazah 'Alamiyah dari al-Azhar pada tahun 1911 ia berkesempatan mengajar di al-Azhar pada tahun 1912 dengan mata kuliah retorika dan sejarah perkembangannya. Akhir tahun 1912 Ali melanjutkan studinya di Inggris. Setahun setelah belajar Bahasa Inggris di London Ali diterima di Oxford University untuk mengikuti kuliah ekonomi dan ilmu politik. ${ }^{8}$

Sekembalinya dari Inggris Ali al-Razik diangkat menjadi hakim pada mahkamah Syari'ah di Mesir pada tahun 1915. Mulanya ditempatkan pada mahkamah Syari'ah Iskandariyah, kemudian pada beberapa provinsi lainnya, sehingga terbitlah bukunya yang berjudul Al-Islam wa Ushul al-Hukm ketika ia bertugas sebagai hakim pada Mahkamah Syari'ah Mansyuriah. ${ }^{9}$

\section{NEGARA SEBAGAI LEMBAGA PEMERINTAHAN ISLAM}

Pengertian Negara cukup banyak. Secara umum adalah bahwa negara ialah suatu lembaga resmi yang memiliki rakyat atau masyarakat, mendiami wilayah atau daerah tertentu dan diorganisir di bawah lembaga politik dan pemerintah yang efektif, mempunyai kesatuan politik, berdaulat sehingga berhak menentukan tujuan nasionalnya dan mendapatkan pengakuan secara internasional. ${ }^{\mathbf{1 0}}$ Negara harus bertugas untuk menegakkan keadilan dalam kehidupan manusia dan mencegah kedhaliman serta menutup kemungkinan terjadinya kesewenangan dalam rangka menegakkan amar ma'ruf dan nahi mungkar. Negara dalam pandangan Islam berdasarkan konstitusi dengan segala perangkat lainnya, dibentuk untuk kepentingan rakyat, sehingga bukan rakyat yang harus mengabdi tanpa reserve kepada Negara.

Kalau rakyat yang harus mengabdi kepada Negara maka rakyatnya menjadi tertekan bagaikan terjajah dan aparat Negara bersifat totaliter. Semua perangkat Negara apalagi pejabat Negara dapat diubah setiap waktu sesuai dengan kehendak rakyat, sepanjang tidak bertentangan dengan agama. ${ }^{11}$

Dalam Islam, tidak dipisahkan antara urusan duniawiyah dengan urusan ukhrawiyah. Keduanya menyatu dalam satu kesatuan yang tak terpisahkan, bagaikan satu mata uang dengan dua sisi yang membangunnya. Dengan kata lain tidak ada pemisahan antara agama dan dunia atau antara Negara dengan agama. Ini dapat dipahami dari firman Allah swt. pada QS. Al-Qashash /28:77 sebagai berikut:

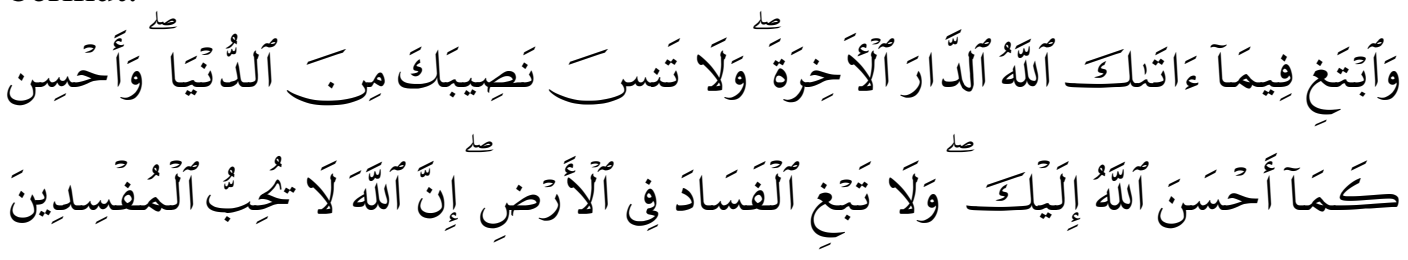

Terjemahnya:

Dan carilah pada apa yang telah dianugerahkan Allah kepadamu (kebahagiaan) negeri akhirat, dan janganlah kamu melupakan bahagianmu dari (kenikmatan) duniawi dan berbuat baiklah (kepada orang lain) 
sebagaimana Allah telah berbuat baik, kepadamu, dan janganlah kamu berbuat kerusakan di (muka) bumi. Sesungguhnya Allah tidak menyukai orang-orang yang berbuat kerusakan.

Islam membawa syariat yang berisi ketentuan hukum yang mengatur masalah kehidupan dunia yaitu hukum perdata, pidana, baik perorangan maupun masyarakat. Dengan demikian Islam menempatkan suatu lembaga Negara sebagai wadah pelaksanaan hukum Islam.

Di dalam syari'at terkandung prinsip umum yang berkait dengan pemerintahan seperti prinsip musyawarah, kemerdekaan, keadilan, dan tolongmenolong. Dengan begitu tidak dapat diragukan bahwa Islam disamping ajaran agama, juga mengatur Negara seperti yang ditunjuk oleh firman Allah swt. pada QS al-Nisa /4 :105:

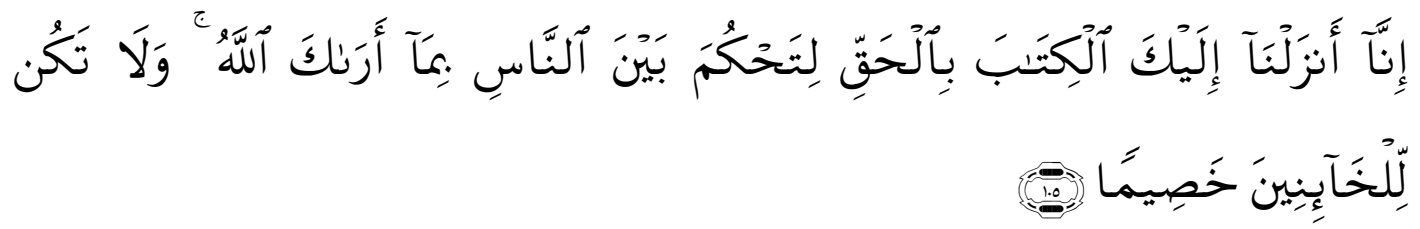

Terjemahnya:

Sesungguhnya Kami telah menurunkan kitab kepadamu dengan membawa kebenaran, supaya kamu mengadili antara manusia dengan apa yang telah Allah wahyukan kepadamu, dan janganlah kamu menjadi penantang (orang yang tidak bersalah), karena (membela) orang-orang yang khianat.

Muhammad saw datang membawa misi Islam yang mengatur kehidupan dunia dan akhirat. Kehidupan beragama membutuhkan Negara sebagai wadah untuk melaksanakan hukum Islam. Pelaksanaan hukum Islam hanya dapat ditegakkan dalam satu wujud lembaga pemerintahan yang diatur dalam satu Negara. Abu Bakar dan khalifah-khalifah sesudahnya bertugas melanjutkan dan mengembangkan system pemerintahan yang telah dibangun pada masa Rasulullah di Madinah. ${ }^{12}$

Sebagai Rasul sekaligus kepala Negara, Muhammad saw. menjalankan roda pemerintahannya dengan baik dan Madinah sebagai pusat pemerintahannya. Sungguhpun demikian, beliau hidup sebagai orang biasa dan tidak meminta sesuatu hak yang istimewa. Sebagai rasul, apa yang datang darinya adalah ajaran agama, sedang sebagai kepala pemerintahan, apa yang datang darinya adalah aturan-aturan yang dihormati dan dijalankan oleh masyarakat sebagai warga Madinah. ${ }^{13}$ Dari sini dipetik satu kesimpulan bahwa institusi pemerintahan sebagaimana yang dicontohkasn oleh Rasulullah saw. menjadi "wajib" dalam hukum Islam. Dengan demikian, maka jika makna dari institusi atau lembaga pemerintahan disepadankan dengan makna dari kata atau istilah Khilafah, maka khilafah menjadi suatu yang wajib ditegakkan oleh umat Islam seluruh dunia.

Menurut Ali Abd al-Razik, ikatan yang dibentuk oleh Nabi pada masanya, bukanlah ikatan politik yang menunjuk pada kwalifikasi suatu Negara atau suatu pemerintahan sebagaimana yang difahami kini. Ikatan yng terbentuk tersebut tidak 
lebih dari ikatan keagamaan yang terlepas dari unsur-unsur kenegaraan, hanya dilandasi oleh kesamaan keyakinan suatu ajaran agama dan tidak oleh ikatan Negara atau system kekuasaan yang bersifat sementara. ${ }^{14}$ Artinya adalah bahwa ikatan yang terbentuk pada masa Rasulullah saw lebih mengarah kepada ikatan persaudaraan sesame muslim, yang lwbih dkenal dengan istilah "Ukhuwwah Diniyyah" dan selanjutnya dengan sesame anak negeri (dengan penganut agamaagama non Islam), yakni "ukhuwwah wathaniyyah"

Hal lain yang perlu digaris bawahi, menurut Ali adalah bahwa Nabi sepanjang hayatnya, tidak pernah memberi petunjuk apapun tentang pembentukan suatu Negara yang biasa disebut "Negara Islam" ataupun "Negara Arab", semantara itu seluruh ulama sepakat bahwa Nabi Muhammad saw. meninggalkan dunia yang fana ini setelah menyelesaikan tugasnya secara sempurna. ${ }^{15}$ Selanjutnya Ali Abd al-Raziq menyatakan bahwa Nabi Muhammad adalah rasul untuk mendakwahkan agama, tidak dicampuri oleh kecenderungan untuk mendirikan kerajaan dan tidak pula mendakwahkan berdirinya suatu Negara. ${ }^{16}$ Dijelaskan pula bahwa Islam sebagai kesatuan agama tidaklah dapat diragukan atas dasar bahwa umat Islam adalah jama'ah yang satu. Nabi mengajak kepada kesatuan tersebut yang sudah terlaksana sebelum beliau wafat. Untuk mencapai kesatuan itu Nabi berjuang dengan lisan dan kekuatannya, kemudian datang pertolongan Allah untuk mencapai kemenangan. ${ }^{17}$

Ali Abd al-Raziq mengakui bahwa jabatan kerasulan penuntut kekuasaan Nabi atas kaumnya. Kekuatan tersebut tidaklah sama dengan kekuasaan raja terhadap rakyatnya yang bersifat materi belaka. Kekuasaan Nabi terhadap kaumnya adalah berupa kekuasaan rohani yang bertolak dari keimanan. ${ }^{18}$

Tampaknya Ali al-Razik mempersamakan antara kekuasaan yang dibangun atas dasar monarki yang kurang memperhatikan hak dan pendapat rakyat. Sementara system pemerintahan yang dibangun oleh Nabi saw. adalah bertolak dari fungsi beliau sebagai mursalin atau pembawa risalah. Fungsi beliau sebagai rasul adalah membimbing manusia ke arah kehidupan agama yang bertakwa kepada Allah, sekaligus berfungsi sebagai kepala Negara yang memiliki wilayah yang berdaulat untuk menerapkan hukum Islam dalam mengatur kehidupan bermasyarakat, berbangsa dan bernegara.

Ali al-Razik memperkuat argumentasinya bahwa rasul diutus tidak dibebani kewajiban selain membawa risalah. Rasul diutus bukan sebagai khafizh (penjaga atau pengawal) Q.S. 4:80, bukan sebagai jabbar (pemaksa Q.S 10:99) dan bukan sebagai Musaitir (penguasa Q.S 88:22). Tetapi kewajiban rasul adalah sebagai Balag atau penyampai risalah (Q.S. 42:48), sebagai Mubasysyir wa Nazir (Q.S. 7:188), sebagai Muzakkir atau pemberi ingat (Q.S. 88:21) sehingga kerajaan senantiasa memerlukan pemaksaan dan kekuasaan yang tak terbatas. ${ }^{19}$

Kalau ditelusuri dalil yang dikemukakan oleh Ali al-Razik, beliau mempersamakan kekuasaan mutlak yang dimiliki oleh Allah swt dengan misi yang diemban oleh Muhammad sebagai rasul Allah. Dengan begitu kerasulan Muhammad cenderung otoriter. Oleh sebab itu tidaklah memberi konotasi bahwa beliau adalah pengawal dan pemaksa ketika mengikuti risalah yang diembannya.

Hal tersebut dianggap oleh ulama al-Azhar Mufti Hudhary Hasan tidak pada tempatnya jika ditinjau dari segi sebab nuzulnya ayat. Seperti yang dikutip 
oleh al-Mutawalli bahwa ayat yang dijadikan dalil oleh Ali al-Razik adalah ayat $\underline{\text { Makkiyah, }}$ sedang pendirian Negara Islam bukan periode Makkiyah, tetapi periode Madinah. Adapun al-Nisa 80, benar turun di Madinah tetapi ayat tersebut turun sebelum perintah jihad. ${ }^{20}$

Adapun hadis yang ditunjuk sebagai dalil oleh Ali Abdul Raziq ialah "Engkau lebih mengetahui urusan duniamu adalah menyangkut perkawinan silang pohon kurma, yang sesuai dengan sebab wurudnya hadis tersebut. Dengan demikian tidak sesuai untuk dijadikan dalil bahwa rasul itu tidak memiliki hak kekuasaan dalam pemerintahan dan Negara. ${ }^{21}$

Sebenarnya hadis tersebut perlu dijadikan dasar dalam mengiaskan masalah social kemasyarakatan yang berkembang yang tidak dirinci dalam al-Qur'an. Operasionalnya diserahkan kepada umat sebagai tuntutan perkembangan, tanpa keluar dari prinsip dasar yang telah diletakkan dalam al-Qur'an dan Sunnah Nabi. Dengan demikian ijtihad sangat diperlukan aktualisasinya dalam kehidupan bernegara untuk mengatur pemerintahan.

Dari sini, Harun Nasution mengamati bahwa system, mempunyai kecenderungan bersifat statis demi untuk mempertahankan eksistensinya. Oleh karena itu dapat mengikat masyarakat dan menghambat perkembangannya. Yang dibutuhkan oleh masyarakat adalah prinsip atau dasar-dasarnya ${ }^{.22}$

Selanjutnya, Ali al Raziq menggaris bawahi bahwa kalau benar tugas Nabi itu juga mendirikan Negara tentu beliau menetapkan pengganti sebelum wafatnya. Dalam kenyataannya, Nabi membiarkan urusan Negara dalam keadaan yang tidak jelas sehingga terjadi perselisihan di kalangan kaum muslimin. Setelah Nabi wafat bentuk kepemimpinan yang baru tidak ada kaitannya dengan risalah dan tidak berdasarkan agama, sehingga Abu Bakar adalah raja yang pertama dalam Islam. ${ }^{23}$ Jika ditelusuri komentar Ali al-Razik bahwa Nabi tidak menunjuk penggantinya sebelum wafat, ini berarti betapa demokratisnya Nabi yang memberikan hak kepada kaum muslimin untuk memilih siapa di antara mereka yang mampu melaksanakan tugas pemerintahan sebagai kepala Negara. Justru seandainya Nabi menunjuk seorang pengganti berarti beliau menggunakan otoritas kekuasaannya sebagai seorang raja yang absolut sekalipun tidak sesuai dengan kehendak rakyat.

Benar terjadi perselisihan pendapat di antara sahabat (muhajirin dan anshar) dalam menentukan siapa yang berhak menjadi khalifah. Tetapi perselisihan itu segera reda dan rukun kembali setelah Abu Bakar terpilih menjadi khalifah dan semua tunduk pada kepemimpinannya.

Bentuk pemerintahan yang benar menurut pandangan al-Qur'an ialah adanya pengakuan Negara, akan kepemimpinan dan kekuasaan Allah dan rasulnya di bidang perundang-undangan. Menyerahkan segala kekuasaan legislative dan kekuasaan hukum tertinggi kepada keduanya dan meyakini bahwa khilafahnya itu, mewakili hakim yang sebenarnya yaitu Allah swt. ${ }^{24}$

Sekalipun Nabi saw. telah mensinyalir dalam hadisnya bahwa 30 tahun sesudah meninggalnya, bentuk pemerintahan khilafah Nabawiyah itu akan berubah menjadi khilafah yang diperintah oleh sultan, yang hal ini terbukti susudah meninnggalnya khalifah Ali bin Abi Thalib. ${ }^{25}$ Namun hal tersebut merupakan dinamika perkembangan pemerintahan Islam yang tidak terlepas dari sikap ambisi 
manusia mengatur kekuasaan dan mempertahankan kedudukannya sebagai kekuatan politik untuk menguasai suatu Negara secara turun-temurun.

\section{MASALAH KHILAFAH}

a. Khilafah dan Sifatnya

Pada dasarnya, kata atau istilah khilafah menunjuk kepada penggantian. Baik yang diganti itu masih ada atau sudah wafat. Selanjutnya, kata tersebut semakna dengan "imamah" yaitu kepemimpinan umum dalam urusan agama sebagai ganti dari Nabi saw. ${ }^{26}$ Istilah "Kerajaan" cendrung dimaknai dengan kekuasaan yang bersifat duniawi, sehingga pada kasus-kasus tertentu, para penguasanya cendrung mengutamakan tuntutan pribadi atau kelompoknya dari tuntutan perjuangan keadilan dan memakmurkan rakyat yang dipimpinnya. Sudah barang tentu kata atau istilah "khilafah" yang merupakan singakatan dari "khilafat alRasul" memiliki makna yang sangat dalam, karena ia mengemban amanah " Rasul untuk menciptakan masyarakat yang “ في الدّنيا حسنة فى الآخرة حسنة

Kalau demikian pengertiannya, maka seorang khalifah haruslah memiliki kualifikasi yang sangat tinggi, seperti antara lain alim dalam agama dan alim dalam tata kelola pemerintahan. Kalau salah satunya tidak dimiliki, niscaya amanah yang diembankan di pundaknya mustahil dapat ditunaikan dengan baik, bahkan sangat boleh jadi, ia akan memerintah lebih buruk dari penguasa yang non khalifah.

Di kalangan sunni, umumnya ulama berpendapat bahwa kedudukan khalifah sama dengan kedudukan Rasul yang tugasnya meliputi urusan agama dan dunia sehingga umat wajib menaatinya, sebagaimana ketaatan mereka kepada Rasul. Ali Abdul Raziq menunjukkan fakta sejarah bahwa perkembangan khilafah ternyata pada akhirnya, memberi peluang menyeleweng dari syari'ah dan sekaligus menafikan pendapat kebanyakan ulama tersebut di atas, kecuali khulafa' al-Rasyidin. ${ }^{27}$ Ibnu Khaldun menegaskan bahwa khalifah yang murni adalah pada masa khulafa' alRasyidin. Sedang dua periode dinasti umayyah dan abbasyiyah antara khilafah dan kerajaan yang di dalamnya terdapat campur aduk yang akhirnya timbul menjadi kerajaan semata dengan segala gelarnya. Khalifah hanya sekedar lambang belaka. ${ }^{28}$

Selanjutnya Ali Abdul Raziq mengomentari bahwa jabatan khalifah yang diberikan kepada Abu Bakar adalah salah satu sumber kesalahan yang berkembang di kalangan kaum muslimin yang mendorong mereka untuk meyakini bahwa lembaga khilafah itu merupakan jabatan keagamaan, yang barang siapa diberi tugas mengurus kepentingan kaum muslimin berarti menempati kedudukannya seperti yang diduduki Nabi. ${ }^{29}$

Pendapat Ali Abdul Raziq ini beranggapan bahwa jabatan khalifah, ada persamaannya dengan kedudukan Nabi sebagai Rasul, padahal kerasulan Nabi Muhammad tidak dapat digantikan oleh siapapun. Namun kedudukan beliau sebagai kepala Negara, qadhi, hakim, dan sebagainya bisa saja digantikan oleh khalifah yang berfungsi sebagai pelaksana pemerintahan Islam secara keseluruhan. 
Pada dasarnya khalifah masih memiliki kedudukan spiritual dan keduniaan yang terbesar dalam dunia Islam. Sebenarnya mereka memperoleh kekuasaan politik yang baru secara independen dan maju selangkah lagi sebagai pelaksana pemerintahan yang kuat. ${ }^{30}$

b. Hukum Khilafah

Ali Abdul Raziq mempertanyakan landasan hukum yang tegas tentang kewajiban menegakkan khilafah menurut Qur'an dan Sunnah. Menurutnya karena tidak ada landasan teologis yang menunjuk wajibnya khilafah sehingga mereka hanya menggunakan ijmak dan logika sehingga status hukumnya tidak jelas, bahkan dalam sunnahpun tidak ada yang menyebutkan soal khilafah. ${ }^{31}$ Pandangan ini sejalan dengan pandangan kaum Khawarij dan Mu'tazilah yang secara tegas menafikan landasan teologis bagi penegakan khilafah. . ${ }^{\mathbf{2}}$

Sudah barang tentu komentar Ali Abdul Raziq tersebut cukup mengejutkan ulama al-Azhar yang menganut mazhab sunni. Dalam mazhab Sunni, menegakkan khilafah adalah diwajibkan oleh syara'. Artinya, mengabaikan penegakan khilafah berarti mengab aikan perintah agama, dan harus dipertanggungjawabkan dihadapan Allah swt. kelak.

Kaitan denghan itu, Sayyid Rasyid Ridha menyebutkan hadis bahwa: barang siapa yang mati dan belum memberikan bai'ah (kepada khalifah/imam) maka matinya mati jahiliyah. Sebelumnya Rasyid Ridha, Ibnu Hazmin al-Dhahiry sudah mengemukakan dalil yang serupa baik Qur'an maupun hadis seperti Q.S. 4:59 dan "Imam itu harus dari golongan Quraisy" (hadis). Semua dalil ini menurut al Raziq tidak dapat dijadikan dalil syara' untuk mengakui adanya khilafah atau imamah dalam arti kepemimpinan untuk menggantikan kedudukan Nabi. ${ }^{33}$

Oleh karena tidak adanya nas, baik Qur'an atau hadis yang tegas tentang hukum khilafah maka timbul bermacam-macam pendapat para ulama dan tidak ada kesepakatan tentang wajibnya khilafah tersebut, yang kadang hanya menggunakan qiyas saja. ${ }^{34}$

c. Tinjauan Teologis

Khilafah Rasyidah (yang baik dan benar) fungsinya bukan hanya menjalankan tatanan Negara serta menjaga keamanan dan membela batasbatas Negara saja. Akan tetapi memikul tanggung jawab menjalankan tatanan "agama yang benar" dan menyatukan segenap kekuatan kaum muslimin di seluruh dunia, daya serta kemampuan social mereka demi menegakkan kalima Allah. ${ }^{35}$

Kedudukan khilafah sejak Abu Bakar hingga hari ini tidak luput dari pertentangan. Dalam sejarah Islam bahwa setiap khalifah hampir tidak sunyi dari kaum separatis yang selalu menentangnya. Kadang dengan kekuatan besar dan terorganisir sekalipun dapat ditumpas oleh kekuatan khalifah atau raja atas dasar kekuatan dan penekanan. Oleh sebab itu khilafah sesudah Khulafa' al-Rasyidin dengan cepat menjadi kerajaan sebagai suatu kedudukan yang terhormat untuk menjamin kesenangan duniawi. ${ }^{36}$ 
Menurut Ali Abdul Raziq bahwa kekhalifahan selamanya hanya merupakan bencana bagi umat Islam. Ia selalu melahirkan kejahatan dan kebobrokan. Dengan menyingkap fakta sejarah sepanjang sejarah kekhalifahan Islam, secara tegas Ali Abdul Raziq menyatakan bahwa persoalan agama dan kehidupan dunia kita, sama sekali tidak mengandung keharusan yang bersifat teologis ditegakkannya institusi khilafah. ${ }^{37}$

Dewasa ini di dunia Islam dua kelompok muslim yang sangat kuat dalam memperjuangkan ditegakkannya kembali "khilafah," yakni kelompok Hizbuttahrir dan kelompok ISIS. Kedua kelompok ini samasama dalam kelompok Islam Sunni, namun dalam perjuangan keduanya menampakkan garis perjuangan yang berbeda. Kelompok Hizbuttahrir lebih cendrung melalui jalur politik dan sosio kultural, sementara kelompok ISIS lebih bersifat militerisme, sehingga terkesan kejam dan menakutkan bagi masyarakat umum. Yang menarik adalah bukan hanya garis perjuangan keduanya yang berbeda, tapi juga tujuan perjuangannya, yakni untuk memenangkan kelompoknya masing-masing. Buktinya adalah, kalau keduanya ditanya tentang tokoh khalifah yang diperjuangkan, jawabannya pasti tidak sama. Kalau demikian, perjuangan keduanya sesungguhnya bukan "li I'la'I kalimatullah" tapi untuk kepentingan masing-masing.

\section{KESIMPULAN}

Pandangan Ali Abdul Raziq sungguh pun lebih berat menggunakan pendekatan sejarah dan logika social, suatu pendekatan yang memang jarang digunakan oleh ulama pada umumnya, namun alasan-alasan teologis dibalik itu cukup kental kelihatan untuk memahami hal terebut, pengkaji perlu lebih kritis.

Kerangka berfikir Ali Abdul Raziq oleh ulama sunni umumnya dianggap cendrung melahirkan Negara sekuler, yaitu Negara yang tidak bertanggungjawab pada persoalan-persoalan agama. Inilah yang menjadi kunci penentangan mereka kepada pemikiran ali Abdul Raziq.

Ali Abdul Raziq menegaskan bahwa dari kaca mata Al-Qur'an maupun Sunnah, tidak ditemukan matan yang bersifat teologis tentang adanya bentuk pemerintahan tertentu yang wajib diikuti atau diterapkan oleh umat Islam. Implikasinya adalah, Rasulullah saw cukup bijak memberi ruang kepada umatnya untuk memilih bentuk pemerintahan yang sesuai untuknya. Oleh karena itu, maka bentuk pemerintahan umat Islam dari masa kemasa tidak bersifat passif, tidak kaku, selalu up to date.

Selanjutnya Ali Abdul Raziq berpendapat bahwa kewajiban khilafah bukan perintah syara'. System pemerintahan umat Islam hendaknya diserahkan kepada umat Islam sendiri untuk memeprtimbangkan system atau bentuk pemerintahan yang mana cocok untuk mereka. Sudah pasti antara satu wilayah dengan wilayah lainnya berbeda sebagaimana juga antara satu kurun waktu dengan kurun waktu lainnya akan berbeda pula.

\section{Endnote}

\footnotetext{
${ }^{1}$ Harun Nasution, Pembaharuan dalam Islam, Sejarah, Pemikiran, dan Gerakan, Cetakan 8 (Jakarta, Bulan Bintang, 1991), hal.151
} 
${ }^{2}$ Lihat Harun Nasution, Pembaharuan dalam Islam, sejarah,pemikiran, dan Gerakan, hal.85

${ }^{3}$ Charles C. Adams, Islam and Modernism in Egypt (London : Oxford University Press Humpry, Milford, 1933), hal.266

${ }^{4}$ Lihat Charles C. Adams, Islam and Modernism in Egypt.

${ }^{5}$ Muhammad Dhiya' al-Din al-Rais, Al-Islam wa al-Khilafah fi al- 'Ashr al-Hadis (Kairo: Dar el-Turats, 1976), hal.57

${ }^{6}$ Lihat Muhammad Dhiya' al-Din al-Rais, Al-Islam wa al-Khilafah fi al-'Ashr al-Hadis, hal.58

${ }^{7}$ Charles C. Adams, Islam and Modernism in Egypt, hal. 259

${ }^{8}$ Lihat Charles C. Adamsm, Islam and Modernism in Egypt, hal.260

${ }^{9}$ Muhammad Dhiya' al-Din al-Rais, Al-Islam wa al-Khilafah fi al- 'Ashr al-Hadis , hal.36

${ }^{10}$ Team penyusun Kamus, Pusat Pembinaan Bahasa. Kamus Besar Bahasa Indonesia, h. 610. Jakarta:

${ }^{11}$ Abu A'la al-Maududi, Al Khilafah wa al-Mulk, terjemahan Muhammad al-Baqir dengan judul: $\quad$ Abu A'la al-Maududi, Al Khilafah wa al-Mulk, hal.31

12 Abdul Hamid Mutawalli, Mabadi' Nizam al-Hukm fi al-Islam (Kairo: Dar elMa'arif,tthn.), hal.98

${ }^{13}$ Hakim Abdul Hameed, Islam at a Glance, Alih Bahasa, Drs. Ruslan Shiddieq dengan judul, Abu A'la al-Maududi, Al Khilafah wa al-Mulk, hal.22

14 John J. Donohue \& John L. Esposito, Islam in Transition Muslim Perspectives, Terjemahan, Islam dan Pembaharuan Ensiklope Masalah-masalah (Jakarta: Rajawali, 1984), hal.47

${ }^{15}$ Lihat John J. Donohue \& John L. Esposito, Islam in Transition Muslim Perspectives, hal. 50

${ }^{16}$ Ali Abd al-Raziq, Al-Islam wa Ushul al-Hukm (Kairo: Al-Muassasat al-Arabiyah, li alDirasah wa al Nasyar, 1972), hal.64

${ }^{17}$ Lihat Ali Abd al-Raziq, Al-Islam wa Ushul al-Hukm, hal.158

${ }^{18}$ Lihat Ali Abd al-Raziq, Al-Islam wa Ushul al-Hukm.

${ }^{19}$ Lihat Ali Abd al-Raziq, Al-Islam wa Ushul al-Hukm, hal.160

${ }^{20}$ Abdul Hamid Mutawalli, Mabadi' Nizam al-Hukm fi al-Islam, hal.107

${ }^{21}$ Lihat, Mabadi' Nizam al-Hukm fi al-Islam, hal.108

${ }^{22}$ Harun Nasution, Islam dan Sistem Pemerintahan sebagai Perkembangan dalam Sejarah, Studi Islamika (Jakarta: LP IAIN Syarif Hidayatullah, 1983), hal.10

${ }^{23}$ Ali Abd al-Raziq, Al-Islam wa Ushul al-Hukm, hal.174. lihat Abdul Hamid Mutawalli, Mabadi' Nizam al-Hukm fi al-Islam, hal.102

${ }^{24}$ Abu A'la al-Maududi, Al Khilafah wa al-Mulk, hal.63

${ }^{25}$ Donald Eugene Smith, Religion, Politic and Social Change in the Third World (New York: The Free Press, 1974), hal.59

${ }^{26}$ Ibnu Khaldun, Muqaddimah ( Mesir: Musthafa Muhammad, tt), hal. 181

${ }^{27}$ Ibnu Khaldun, Muqaddimah, hal.194. lihat Erwin I.J. Rosenthal, Islam in The Modern National State (Cambridge: Cambridge at The University Press, 1965), hal.81

${ }^{28}$ Lihat Ibnu Khaldun, Muqaddimah). hal.196

${ }^{29}$ Jhon J. Donohue \& Jhon L: Esposito: Islam in Transition Muslim Perspectives), hal.52

${ }^{30}$ S. Khuda Bakhsh, Politics in Islam, Published by Muhammad Ahmad for Idarah-I Adabiyat-I ( Delhi: Qasimjan street, 1975), hal.125

${ }^{31}$ Ali al-Raziq, Al-Islam wa Ushul al-Hukm, hal.122

${ }^{32}$ Lihat Ali al-Raziq, Al-Islam wa Ushul al-Hukm, hal.123

${ }^{33}$ Lihat Ali al-Raziq, Al-Islam wa Ushul al-Hukm, hal.124

${ }^{34}$ Lihat Ali al-Raziq, Al-Islam wa Ushul al-Hukm, hal.122

${ }^{35}$ Abu al-A'la al-Maududi, Al Khilafah wa al-Mulk, hal.135

${ }^{36}$ Ali Abd al-Raziq, Al-Islam wa Ushul al-Hukm, hal.128

${ }^{37}$ Lihat Ali al-Raziq, Al-Islam wa Ushul al-Hukm, hal.136 


\section{DAFTAR KEPUSTAKAAN}

Abu al-A'la al-Maududy, al-Khilafah wa al-Mulk, Terjemahan Muhammad alBaqir, dengan judul Khilafah dan Kerajaan, Cet: I; Bandung: Mizan, 1984.

Abdul Hamid Mutawalli. 1974. Mabadi' Nizam al-Hukmi fi al-Islam, dar el Ma'arif: Kairo

Ali Abd al-Raziq. Al-Islam wa Ushul al-Hukm, Editor Muhammad 'Ammarah, alMuassat al-Adabiyat Li al-dirasat wa al-Nasyar, 1972.

Charles, C. Adams. Islam and Modernism in Egypt. London Oxford University Press, Humpry Milpord, 1933.

Donald Eugene Smith. Religion, Politic, and Social Change in the third world. The Free Press. New York Devision of Macmil Publishing, 1974.

D.S. Margoliuth at al. The Renaissance of Islam. Idarah-i-Adabiyat-I Delli, Qasimjan street, Delhi-6-, 1969.

Erwin I.J. Rosenthal, Islam in the Modern National, St.te Cambridge at the University press, 1991.

Harun Nasution Prof. Dr, Pembaharuan dalam Islam Sejarah Pemikiran dan gerakan, cetakan 8, Jakarta: Bulan Bintang

--------- Islam dan System Pemerintahan sebagai Perkembangan dalam Sejarah, Study Islamika, Jakarta: LP IAIN Syarif Hidayatullah, 1983.

Hakic Abdul Hameed, Islam at the Glance, alih Bahasa Drs. Ruslan Siddieq. Aspek-aspek Pokok Agama Islam, Jakarta: Pustaka Jaya, 1983.

Ibnu Khaldun, Muqaddimah. Mesir: Mustafa Muhammad, tth

John J. Donohue \& John L. Esposito, Islam in Transition Muslim Perspectives, terjemahan Drs. Machnun Husein, Islam dan Pembaharuan, Ensiklopedi Masalah-masalah, Jakarta: Rajawali, 1984.

Muhammad Dhiya' al-Dien al-Rais, Al Islam wa al-Khilafah fi al-'Ashar alHadits, Kairo: Dar el Turats, 1976.

S.Khuda Bakhsh, Politic in Islam, Published by Muhammad Ahmad for Idarah-iAdabiyat-I, Qasimjan street, Delhi, 1975.

Team Penyusun Kamus. Pusat Pembinaan dan Pengembangan Bahasa, Kamus Besar Bahasa Indonesia (Cet. II; Jakarta: Balai Pustaka), 1989. 